\title{
Effect of stenting and non-stenting prior to extra corporeal shock wave lithotripsy of inferior calyceal stones: a comparative study
}

\author{
Jose Binu*, Rajan Vysakh
}

Department of General Surgery, Amala Institute of Medical Sciences, Amala Nagar, Thrissur 680 555, Kerala, India

Received: 13 November 2015

Accepted: 16 December 2015

\author{
*Correspondence: \\ Dr. Jose Binu, \\ E-mail: drbinujose@yahoo.com
}

Copyright: $(\odot$ the author(s), publisher and licensee Medip Academy. This is an open-access article distributed under the terms of the Creative Commons Attribution Non-Commercial License, which permits unrestricted non-commercial use, distribution, and reproduction in any medium, provided the original work is properly cited.

\begin{abstract}
Background: The rational of using ureteral stents can reduce the complications after extra corporeal shock wave lithotripsy (ESWL) and contribute to successful stone passage. However, the insertion of double $\mathbf{J}$ stents during ESWL is controversial. This study was aimed to determine whether the stenting prior to ESWL will increase the stone clearance rate in patients with inferior calyceal calculi and also to study the influence of stone size in the stone fragmentation and clearance.

Methods: Patients who had lower ureteric calculi of size ranging from 5-20 mm in diameter and treated with ESWL were included. A detailed history, gender, stone side, stone size, features like dysuria, pyuria, frequency and urgency were taken and compared to that of non-stented group of patients.

Results: Total 52 patients (36 males and 16 females) were included in the randomized prospective study. Gender, stone side and stone nature had no significant influence on clearance ( $p>0.05)$. Features like dysuria, pyuria, frequency and urgency showed significant correlation with stented patients. Of 52 patients, 27 had stone size more than $1 \mathrm{~cm}$ and 25 had stone size less than $1 \mathrm{~cm}$. A statistically significant percentage of stone clearance $(80 \%)$ was found among stented patients with stone size more than $1 \mathrm{~cm}$.

Conclusions: Stenting prior to ESWL significantly increases the stone clearance rate in patients with inferior calyceal calculi of size $>1 \mathrm{~cm}$. Parameters like gender side or stone nature had no influence in clearance following ESWL. Frequency, urgency, dysuria and pyuria were significantly more in stented patients.
\end{abstract}

Keywords: Corporeal shock wave lithotripsy, Double J stenting, Renal calculi, Dysuria, Pyuria

\section{INTRODUCTION}

Thrombo-angitis obliterans (Buerger's disease) is an extra corporeal shock wave lithotripsy (ESWL) is a non invasive technique for treating patients with renal calculi. It fragments the stone to smaller size which ease its passage through distal urinary tracts. It brings along with it a set of complications like those related to stone fragmentation, stone passage, and infection due to its effect on renal and extra renal tissues. ${ }^{1}$ Incomplete fragmentation may cause the residual stones to block the ureters, a condition described by term "Steinstrasse" meaning "stone street". 1,2 The insertion of DJ stents during ESWL of renal calculi is controversial. The older rationale was Double $\mathrm{J}$ stenting showed significant advantages in ESWL patients, particularly to resolve the problem of steinstrasse. ${ }^{3}$

Complications that were attributed to indwelling ureteral stents had concluded that ureteral stents do not reduce post-SWL complications and they were clearly associated with morbidity. Furthermore, it did not improve stone passage markedly. ${ }^{3}$ Even in patients with stone burden of more than $2 \mathrm{~cm}$ treatment without stenting was recommended. This study was aimed to find the extent of ureteral stent affected stone fragments passage in patients 
who underwent SWL with inferior calyceal stones less than $2 \mathrm{~cm}$ in diameter and also to study whether stone size influences stone fragmentation and clearance in inferior calyceal stones.

\section{METHODS}

\section{Patients' selection}

This randomized prospective study was conducted in the department of Urology, Govt. Medical College, Kozhikode, Kerala, India November 2013 to December 2014. Fifty two patients with unilateral or bilateral inferior calyceal stone of size ranging from 5 to $20 \mathrm{~mm}$ were included in the study. Patients were randomly assigned into two groups. Group A (23 pts) was stented with 6 Fr DJ stent prior to ESWL with standard procedure as described by Sulaiman et $\mathrm{al}^{4}$ and Group B (29 pts) was given ESWL without stenting. All patients were given shocks in the range of 2000-3000 at $1 \mathrm{~Hz}$ with a DIREX-COMPACT XL Lithotripter. All patients were given diuretics and alpha blockers post procedure. Pre procedural imaging comprised KUB, intravenous urography films and ultrasound of the kidney and upper ureter. Post procedural imaging was performed by KUB films immediately after the session to evaluate fragmentation, then at 2 weeks to detect clearance and assess the need for further treatments, as well as at 1 and 3 months to evaluate complete clearance. Successful ESWL was defined as either complete stone clearance with the lack of any visible fragments on radiological studies or the presence of clinically insignificant fragments of size $4 \mathrm{~mm}$. Patients with recent open or endoscopic surgical intervention, radiolucent calculus, multiple stone, distal obstructions, and children were excluded. Consent was obtained from the patient or their relatives and the study design was approved by the Institutional ethics committee for research.

\section{Statistical analysis}

Analysis was done using statistical software SPSS (Version 16). Chi square test was used to know the significant difference between the groups. $\mathrm{P}<0.05$ was considered as significant.

\section{RESULTS}

Total of 52 patients were included in the study of which there were 36 males and 16 females (Figure 1). Radiologically, stone density was comparable in both groups. Lower infundibulo pelvic angle (LIP-A) $>70$, infundibular length $<30 \mathrm{~mm}$ and infundibular width $>5$ $\mathrm{mm}$ were considered favourable anatomy (Figure 2). ${ }^{5}$

There was no statistically significant correlation between sex of the patient and stone clearance $(\mathrm{p}=0.425)$ (Table 1). Among 52 patients, 29 had stone on the right side (14 stented and 15 non stented) and 23 patients had calculi on left (9 stented and 14 non stented). A total of 52, 90.3\% patients had de novo stones and $9.6 \%$ patients had recurrent stones. There were no statistical significance among stented and non stented patients with respect to stone side and stone nature $(\mathrm{p}=0.515$ and $\mathrm{p}=0.287$, respectively) (Table 1 ).

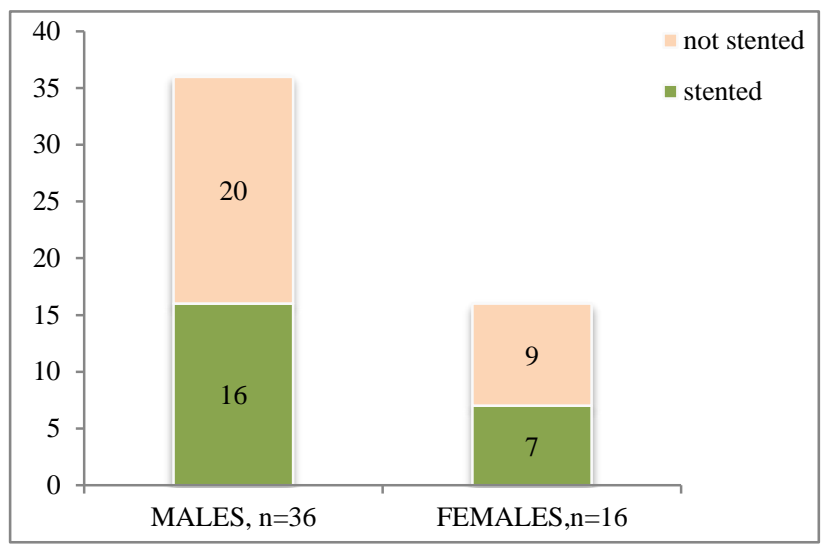

Figure 1: Distribution of patients.

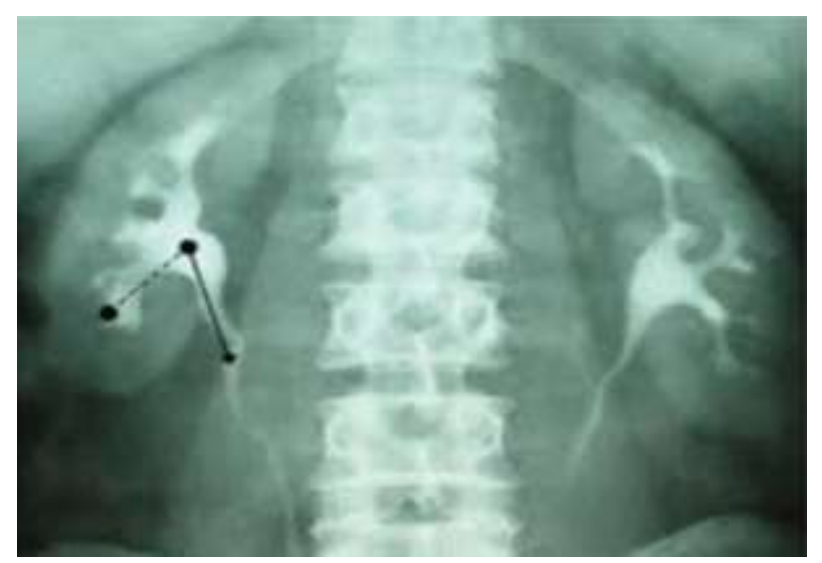

Figure 2: Intravenous urogram showing lower infundibulopelvic angle.

Table 1: Patient and stone characteristics.

\begin{tabular}{|c|c|c|c|c|}
\hline & & Stented & No stented & p value \\
\hline \multirow{2}{*}{ Gender } & Males & 16 & 20 & \multirow{2}{*}{0.425} \\
\hline & Females & 7 & 9 & \\
\hline \multirow{2}{*}{$\begin{array}{l}\text { Stone } \\
\text { side }\end{array}$} & Right & 14 & 15 & \multirow{2}{*}{0.515} \\
\hline & Left & 9 & 14 & \\
\hline \multirow{2}{*}{$\begin{array}{l}\text { Stone } \\
\text { nature }\end{array}$} & De novo & 21 & 26 & \multirow{2}{*}{0.287} \\
\hline & Recurrent & 2 & 3 & \\
\hline
\end{tabular}

Various morbidity such as dysuria, pyuria, microscopic hematuria, gross hematuria frequency, supra pubic pain and urgency were studied among stented and non stented patients. Overall $28.8 \%$ patients had dysuria, $26.9 \%$ had pyuria, $17.3 \%$ had microscopic hematuria, $1.9 \%$ had gross hematuria, $21.1 \%$ had increased frequency, $13.4 \%$ had supra pubic pain and $23.0 \%$ had urgency (Table 2). Of these dysuria, pyuria, frequency and urgency had significant correlation with stented patients $(p=0.004, p=$ 
$0.014, p=0.024, p=0.006$, respectively). Analysis of correlation between stone size and stone clearance showed that $84 \%$ patients had stone clearance when the stone size was less than $1 \mathrm{~cm}$ (Table 3 ).

Table 2: Morbidity in stented versus nonstented cases.

\begin{tabular}{|lllll|}
\hline & Overall & Stented & $\begin{array}{l}\text { Not } \\
\text { stented }\end{array}$ & p value \\
\hline Dysuria & 15 & 12 & 3 & 0.004 \\
\hline Pyuria & 14 & 10 & 4 & 0.014 \\
\hline $\begin{array}{l}\text { Microscopic } \\
\text { hematuria }\end{array}$ & 9 & 6 & 3 & 0.585 \\
\hline $\begin{array}{l}\text { Gross } \\
\text { hematuria }\end{array}$ & 1 & 1 & 0 & 0.367 \\
\hline Frequency & 11 & 8 & 3 & 0.024 \\
\hline $\begin{array}{l}\text { Supra pubic } \\
\text { pain }\end{array}$ & 7 & 4 & 3 & 0.256 \\
\hline Urgency & 12 & 10 & 2 & 0.006 \\
\hline
\end{tabular}

Table 3: Correlation between stone size and stone clearance.

\begin{tabular}{|llll|}
\hline Stone size & Groups & $\begin{array}{l}\text { Stone } \\
\text { cleared }\end{array}$ & $\begin{array}{l}\text { Stone not } \\
\text { cleared }\end{array}$ \\
\hline$<1 \mathrm{~cm}$ & 25 & $21(84 \%)$ & $4(16 \%)$ \\
\hline$>1 \mathrm{~cm}$ & 27 & $15(55.6 \%)$ & $12(44.4 \%)$ \\
\hline
\end{tabular}

Chi-Square $=4.930(\mathrm{p}=0.026)$

Table 4: Clearance of stones among the patients with size of stone less than $1 \mathrm{~cm}$.

\begin{tabular}{|c|c|c|c|c|}
\hline & Groups & & $\begin{array}{l}\text { Stone } \\
\text { cleared }\end{array}$ & $\begin{array}{l}\text { Stone not } \\
\text { cleared }\end{array}$ \\
\hline \multirow{2}{*}{$\begin{array}{l}\text { Stone size } \\
<1 \mathrm{~cm} \\
(25 \mathrm{pts})\end{array}$} & Stented & 8 & $7(87.5 \%)$ & $1(12.5 \%)$ \\
\hline & $\begin{array}{l}\text { Not } \\
\text { stented }\end{array}$ & 17 & $14(82.4 \%)$ & $3(17.6 \%)$ \\
\hline
\end{tabular}

Chi-Square $=1.982(\mathrm{p}>0.05)$

Table 5: Fragmentation of stones among the patients with size of stone more than $1 \mathrm{~cm}$.

\begin{tabular}{|c|c|c|c|c|}
\hline & Groups & & $\begin{array}{l}\text { Stone } \\
\text { fragmented }\end{array}$ & \multirow{3}{*}{$\begin{array}{l}P= \\
0.467\end{array}$} \\
\hline \multirow{2}{*}{$\begin{array}{l}\text { Stone } \\
\text { size } \\
>1 \mathrm{~cm} \\
(27 \mathrm{pts})\end{array}$} & Stented & 15 & $12(80 \%)$ & \\
\hline & Not stented & 12 & $9(75 \%)$ & \\
\hline
\end{tabular}

Among patients with stone size $<1 \mathrm{~cm}, 8$ patients were stented and 17 patients were not stented. There were $87.5 \%$ clearance among stented and $82.4 \%$ clearance among non stented patients. The data didn't show statistical significance, $\mathrm{p}=0.0169$ (Table 4). Only 80\% patients had stone fragmentation among stented group and $75 \%$ among non stented group. The analysis showed a $\mathrm{p}$ of 0.467 which points the fact that stenting doesn't contribute to stone fragmentation when stone size is more than $1 \mathrm{~cm}$ (Table 5). 27 patients had stone size more than
$1 \mathrm{~cm}$. Among the stented 15 patients, 80\% had stone clearance and only $25 \%$ stone clearance among non stented group. Chi square test gave a p value of 0.034 (Table 6).

Table 6: Clearance of stones among the patients with size of stone more than $1 \mathrm{~cm}$.

\begin{tabular}{|lllll|}
\hline & & & $\begin{array}{l}\text { Stone } \\
\text { cleared }\end{array}$ & $\begin{array}{l}\text { Stone } \\
\text { not } \\
\text { cleared }\end{array}$ \\
\cline { 2 - 5 } $\begin{array}{l}\text { Stone } \\
\text { size } \\
>1 \mathrm{~cm} \\
(27 \mathrm{pts})\end{array}$ & Stented & 15 & $12(80 \%)$ & $3(20 \%)$ \\
\hline
\end{tabular}

Chi-Square $=6.425(\mathrm{p}=0.034)$

\section{DISCUSSION}

ESWL is the first choice for the treatment of lower pole calyceal stones up to $1 \mathrm{~cm}$ and favored by urologists and patients because it is the only non invasive therapy option and can be performed without anesthesia in outpatient set up. There was always a controversial debate whether lower pole stones are a good target for ESWL therapy. A prospective randomized trial showed that there is poor stone clearance for lower pole stone especially of size greater than $10 \mathrm{~mm}$ following shock wave lithotripsy. ${ }^{6}$

The disintegration rate of lower calyceal stones treated by ESWL is comparable to stones in other locations within the kidney. A study on 687 patients on the efficacy of extracorporeal shock wave lithotripsy for isolated lower pole calculi compared with isolated middle and upper calyceal calculi recommended that ESWL as the primary treatment of choice for calculi less than $2.0 \mathrm{~cm}$ in all calyceal locations. ${ }^{7}$ However, the role of lower of calyceal anatomy to predict the success of ESWL is controversial. Previous study showed that, rather than calyceal anatomy, stone size is a better predictor of outcome. ${ }^{8}$ Another study on pediatric age group showed that there was no significance for lower calyceal pelvic anatomy with regard to stone clearance after SWL. ${ }^{9}$ Due to the unfavorable spatial anatomy of the lower pole collecting system, the clearance of the fragments was not as likely. In another study, it was shown that placement of DJ stents were for free stone rate or enhancing passage of the fragments during SWL in renal stones with diameter less than $2.5 \mathrm{~cm}^{10}$

In our study, we found better stone clearance rate of lower calyceal stones $>1 \mathrm{~cm}$ treated by ESWL, after stenting, probably because of better fragment passage by ureteric stent. But symptoms like frequency, urgency, dysuria and pyuria were significantly more in patients with DJ stents, a finding which is in accordance with previous studies. ${ }^{11}$ The limitations of this study such as difference in sample size in groups such as between de novo stones and recurrent stones, or between stented and 
non stented patients of stone size of less than $1 \mathrm{~cm}$ warranted a detailed multicentre study.

\section{CONCLUSION}

Stenting prior to ESWL significantly increases the stone clearance rate in patients with inferior calyceal calculi of $>1 \mathrm{~cm}$ size but not beneficial in stone clearance in cases of stone size $<1 \mathrm{~cm}$. Success rate of ESWL was significantly increased when stone size is $<1 \mathrm{~cm}$ in both stented and non- stented group. Parameters like gender, stone side, or stone nature had no influence in clearance following ESWL. Frequency, urgency, dysuria and pyuria were significantly more in stented patients.

\section{ACKNOWLEDGEMENTS}

Authors gratefully acknowledge the valuable help of Dr. Ajith TA., Professor, Department of Biochemistry, Amala Institute of Medical Sciences, Thrissur, Kerala, India during the preparation of the manuscript.

Funding: No funding sources

Conflict of interest: None declared

Ethical approval: The study was approved by the institutional ethics committee

\section{REFERENCES}

1. D'Addessi A, Vittori M, Racioppi M, Pinto F, Sacco E, Bassi P. Complications of extracorporeal shock wave lithotripsy for urinary stones: to know and to manage them-A review. Scientific World J. 2012:619820.

2. Chaussy C, Schmiedt E. Extracorporeal shock wave lithotripsy (ESWL) for kidney stones. An alternative to surgery? Urologic Radiol. 1984;6:80-7.

3. Shen P, Jiang M, Yang J, Li X, Li Y, Wei W, et al. Use of ureteral stent in extracorporeal shock wave lithotripsy for upper urinary calculi: a systematic review and meta-analysis. J Urol. 2011;186:132835.
4. Sulaiman MN, Buchholz NP, Clark PB. The role of ureteral stent placement in the prevention of Steinstrasse. J Endourol. 1999;13:151-5.

5. Elbahnasy AM, Shalhav AL, Hoenig DM, Elashry OM, Smith DS, McDougall EM. Lower caliceal stone clearance after shock wave lithotripsy or ureteroscopy: the impact of lower pole radiographic anatomy. J Urol. 1998;159:676-2.

6. Albala DM, Assimos DG, Clayman RV, Denstedt JD, Grasso M, Gutierrez-Aceves J. Lower pole I: a prospective randomized trial of extracorporeal shock wave lithotripsy and percutaneous nephrostolithotomy for lower pole nephrolithiasisinitial results. J Urol. 2001;166:2072-80.

7. Obek C, Onal B, Kantay K, Kalkan M, Yalçin V, Oner A. The efficacy of extracorporeal shock wave lithotripsy for isolated lower pole calculi compared with isolated middle and upper caliceal calculi. J Urol. 2001;166:2081-4.

8. Onal B, Demirkesen O, Tansu N, Kalkan M, Altintaş R, Yalçin V. Is lower pole caliceal anatomy predictive of extracorporeal shock wave lithotripsy success for primary lower pole kidney stones? J Urol. 2002; 168:2377-82.

9. Onal B, Demirkesen O, Tansu N, Kalkan M, Altintaş R, Yalçin V. The impact of caliceal pelvic anatomy on stone clearance after shock wave lithotripsy for pediatric lower pole stones. J Urol. 2004;172:1082-86.

10. Mustafa M, Ali-El-Dein B. Stenting in extracorporeal shockwave lithotripsy; may enhance the passage of the fragments! J Pak Med Assoc. 2009;59:141-3.

11. Musa AA. Use of double-J stents prior to extracorporeal shock wave lithotripsy is not beneficial: results of a prospective randomized study. Int Urol Nephrol. 2008;40:19-22.

Cite this article as: Binu J, Vysakh R. Effect of stenting and non-stenting prior to extra corporeal shock wave lithotripsy of inferior calyceal stones: a comparative study. Int Surg J 2016;3:226-9. 